\title{
Karyological Investigation on Seven Centaurea L. (Asteraceae) Taxa from Turkey
}

\author{
Neslihan Tasar ${ }^{1}$, Gulden Dogan ${ }^{2 *}$ and Yasar Kiran ${ }^{2}$ \\ ${ }^{1}$ Munzur University, Tunceli Vocational School, Department of Organic Agriculture, Tunceli, Turkey \\ ${ }^{2}$ Firat University, Science Fac., Biology Department, Elazig, Turkey
}

Received March 29, 2018; accepted May 1, 2018

\begin{abstract}
Summary The somatic chromosome numbers and karyotypes were examined in seven species of genus Centaurea L. distributed in Turkey. The chromosome numbers were determined as $2 n=2 x=16$ in $C$. behen L. and $C$. solstitialis L.; $2 n=2 x=18$ in C. cynarocephala Wagenitz and C. agregata Fisch. \& Mey. ex DC. ssp. agregata; $2 n=2 x=20$ in C. iberica Trev. ex Sprengel; $2 n=2 x=26$ in C. balsamita Lam.; $2 n=4 x=36$ in C. virgata Lam. All of the chromosomes had centromeres at median point $(\mathrm{M})$, median region $(\mathrm{m})$, and submedian region (sm). Satellite chromosomes (sat-chromosomes) were observed only in C. virgata. The findings for each of the analyzed taxa are compared each other and with the results of previous studies.
\end{abstract}

Key words Asteraceae, Centaurea, Chromosome number, Karyotype, Turkey.

The genus Centaurea L. is a polymorphous genus belonging to the tribe Cardueae Cass. of the family Asteraceae, and comprises 400-700 species of annual, biennial and perennial grasses, rarely dwarf shrubs predominantly distributed in Europe and Asia (Dittrich 1977, Wagenitz and Hellwig 1996, Bancheva and Greilhuber 2006). Centaurea is considered a taxonomically unnatural group and recent approaches have split this taxon into four genera of Centaurea s.str., Cyanus Miller, Psephellus Cassini, and Rhaponticoides Vaillant (Greuter 2003, Hellwig 2004).

Common names for Centaurea species is a star-thistle, corn flower, and knapweed. Their Turkish names are "peygamber çiçeği", "zerdali dikeni", "çoban kaldiran" and "Timur dikeni" (Baytop 1999). Generally, Centaurea is grown on various habitats of stony calcareous cliffs, vineyards, roadsides, seashores, gypsum fields, open woods and shrubs, waste places, steppe, fallow fields, maquis, sandy beaches, forests, dry meadows, rocky slopes and on maritime limestone cliffs in Turkey. Particularly the aerial parts with flowers or only flowers of some Centaurea species are used in Turkish folk medicine to alleviate a wide range of symptoms (Yesilada et al. 2004, Gurbuz and Yesilada 2007).

In Turkey, the Centaurea is represented by 182 species including 113 endemics, distributed particularly in the southwest, central and eastern parts of the country (Davis 1975, Altintas et al. 2004). The ratio of endemic species to common species is quite high of $62.1 \%$. Turkey is one of the main centers of diversity for the Centaurea (Wagenitz 1986). It is ca. 195 Centaurea species

\footnotetext{
* Corresponding author, e-mail: gdogan@firat.edu.tr

DOI: $10.1508 /$ cytologia.83.317
}

growing in Turkey (Wagenitz 1975, Wagenitz and Hellwig 1997, Davis et al. 1988, Guner 2000).

A close correlation among karyology, pollen morphology and systematic in the subtribe Centaureinae have been demonstrated where basic chromosome numbers are considered a key character for sectional classification (Romaschenko et al. 2004, Garcia-Jacas et al. 2006). The basic chromosome number of Centaurea is known to be $x=7-15$ (Gomurgen 2006).

Centaurea is a taxonomically complicated genus because it contains many species that show a great degree of morphological variations. Therefore, analyses of karyomorphological features are important for the revision and systematics. The purpose of this study was to improve the knowledge of karyomorphological features of Centaurea species in Turkey.

\section{Materials and methods}

Plant materials of seven species were collected from natural habitats during the fruiting season between 2011 and 2013. The localities geographical position, altitude, and voucher number of the species are presented in Table 1 . The voucher specimens were deposited at the Firat University Herbarium.

The karyological studies are conducted on the meristematic cells of root tips. The seeds were germinated on a moist filter paper in Petri dishes at $25^{\circ} \mathrm{C}$. The actively growing root tips were pretreated with $0.05 \%$ colchicine for $3-3.5 \mathrm{~h}$ at room temperature. Afterwards, the root tips were fixed with Carnoy fixative $(1: 3$ glacial acetic acid-absolute ethanol) for at least $24 \mathrm{~h}$ at $4^{\circ} \mathrm{C}$, hydrolyzed in $1 \mathrm{M} \mathrm{HCl}$ at $60^{\circ} \mathrm{C}$ for $15 \mathrm{~min}$, then rinsed in tap water for 3-5 min. Finally, they were stained in the Feulgen 
Table 1. Localities and voucher numbers of Centaurea taxa investigated.

\begin{tabular}{|c|c|c|}
\hline Taxa & Locality & Voucher number \\
\hline $\begin{array}{l}\text { C. aggregata } \\
\text { subsp. aggregata }\end{array}$ & Elazı̆̆: Palu Baltaşı köyü Baltaşı karakolu arkası, 1450 m, 02.07 .2013 & Tasar 1092 \\
\hline C. virgata & Elazığ: Baskil Kayabeyli köyü, yol kenarı, 1100 m, 18.06.2012 & Tasar 1071 \\
\hline C. balsamita & Elazı̆̆: Elazığ Işıkyolu köyü, yol kenarı, 1150 m, 02.07.2012 & Tasar 1083 \\
\hline C. behen & Elazığ: Keban yolu, Beşik köyü girişi, yol kenarı, 1090 m, 15. 07. 2012 & Tasar 1085 \\
\hline C. cynarocephala & Elazığ: Sivrice Gözeli köyü, Kuşakçı dağı, 1750 m, 23.06.2012 & Tasar 1075 \\
\hline C. iberica & Elazı̆̆: Sürsürü Mahallesi, 1067 m, 22.06.2011 & Tasar 1051 \\
\hline $\begin{array}{l}\text { C. solstitialis } \\
\quad \text { subsp. solstitialis }\end{array}$ & Elazığ: Sürsürü Mahallesi, 1067 m, 22.06.2011 & Tasar 1052 \\
\hline
\end{tabular}

Table 2. Somatic chromosome number (2n), ploidy level, karyotype formula, chromosome length range (CLR), total length of haploid complement (THC), relative length (RL), arm ratio (AR), centromeric index (CI), the intrachromosomal and interchromosome asymmetry index of Romero Zarco $\left(\mathrm{A}_{1}, \mathrm{~A}_{2}\right)$ and Stebbins' types of karyotype asymmetry $(\mathrm{SC})$ the studied Centaurea taxa.

\begin{tabular}{|c|c|c|c|c|c|c|c|c|c|c|c|}
\hline Taxa & $2 n$ & $\begin{array}{l}\text { Ploidy } \\
\text { level }\end{array}$ & $\begin{array}{l}\text { Karyotype } \\
\text { formula }\end{array}$ & CLR $(\mu \mathrm{m})$ & $\begin{array}{l}\mathrm{THC} \\
(\mu \mathrm{m})\end{array}$ & RL (\%) & AR & CI & $\mathrm{A}_{1}$ & $\mathrm{~A}_{2}$ & $\mathrm{SC}$ \\
\hline $\begin{array}{l}\text { C. aggregata } \\
\quad \text { subsp. aggregata }\end{array}$ & 18 & $2 x$ & $1 \mathrm{M}+5 \mathrm{~m}+3 \mathrm{sm}$ & $3.65-7.51$ & 42.84 & $8.52-17.53$ & $1.00-2.08$ & $32.41-50.00$ & 0.34 & 0.26 & $2 \mathrm{~B}$ \\
\hline C. virgata & 36 & $4 x$ & $3 \mathrm{M}+8 \mathrm{~m}+7 \mathrm{sm}$ & $1.63-6.00$ & 63.47 & $2.56-9.45$ & $1.00-3.60$ & $22.37-50.00$ & 0.34 & 0.28 & $2 \mathrm{~B}$ \\
\hline C. balsamita & 26 & $2 x$ & $1 \mathrm{M}+7 \mathrm{~m}+5 \mathrm{sm}$ & $1.60-4.22$ & 33.94 & $4.71-12.43$ & $1.00-2.36$ & $29.68-50.00$ & 0.35 & 0.25 & $2 \mathrm{~B}$ \\
\hline C. behen & 16 & $2 x$ & $3 \mathrm{M}+4 \mathrm{~m}+1 \mathrm{sm}$ & $3.07-4.03$ & 27.81 & $11.03-14.49$ & $1.00-1.76$ & $36.22-50.00$ & 0.14 & 0.10 & $1 \mathrm{~A}$ \\
\hline C. cynarocephala & 18 & $2 x$ & $1 \mathrm{M}+6 \mathrm{~m}+2 \mathrm{sm}$ & $3.18-6.41$ & 40.15 & $7.89-15.96$ & $1.00-2.79$ & $26.37-50.00$ & 0.34 & 0.21 & $2 \mathrm{~B}$ \\
\hline C. iberica & 20 & $2 x$ & $1 \mathrm{M}+8 \mathrm{~m}+1 \mathrm{sm}$ & $1.57-2.95$ & 21.93 & $7.15-13.45$ & $1.00-2.03$ & $32.97-50.00$ & 0.28 & 0.19 & $2 \mathrm{~A}$ \\
\hline $\begin{array}{l}\text { C. solstitialis } \mathrm{L} \text {. } \\
\text { subsp. solstitialis } \mathrm{L}\end{array}$ & 16 & $2 x$ & $1 \mathrm{M}+4 \mathrm{~m}+3 \mathrm{sm}$ & $1.81-3.53$ & 19.80 & $9.14-17.82$ & $1.00-2.09$ & $32.29-50.00$ & 0.28 & 0.21 & $2 \mathrm{~A}$ \\
\hline
\end{tabular}

reagent for $1 \mathrm{~h}$ and mounted in $45 \%$ acetic acid (Kiran et al. 2012). Digital microphotographs from at least five well-spread metaphase plates were taken using an Olympus BX51 microscope and an Olympus Camedia C-4000 digital camera.

The chromosome numbers of the species were identified and checked using the Flora of Turkey (Davis 1975) and supplements (Davis et al. 1988, Guner 2000). Also, relevant literature (Tamamschian 1963, Kazmi 1964) and the online chromosome number databases, Index to Plant Chromosome Numbers (http://www.tropicos. org/Project/IPCN) and Index to Chromosome Numbers in Asteraceae (Info-Lib Index to Chromosome Numbers in Asteraceae, http://www.lib.kobe-u.ac.jp/infolib/ meta_pub/G0000003asteraceaesresult-en) were checked.

\section{Results}

The number of somatic chromosomes, ploidy level, karyotype formula (Levan et al. 1964), chromosome length range, total length of the haploid complement, relative length, arm ratio, centromeric index, $A_{1}$ and $A_{2}$ values (Romero Zarco 1986), types for karyotype asymmetry (Stebbins 1971) were determined for each taxa (Table 2). Somatic metaphase chromosomes and idiograms are given in Figs. 1 and 2. The examined taxa and characteristics of somatic chromosomes are given below.

C. aggregata Fisch. \& Mey. ex DC. ssp. aggregata: This taxon growing on dry rocky slopes and forests between altitudes of 700 and $1800 \mathrm{~m}$ (Davis 1975). The somatic chromosome number of this species was found to be $2 n=18$. The chromosome length ranges 3.65 to $7.51 \mu \mathrm{m}$ and the total length of the haploid complement was $42.84 \mu \mathrm{m}$. It consists of $1 \mathrm{M}, 5 \mathrm{~m}$, and $3 \mathrm{sm}$ chromosomes. Chromosome arm ratios are 1.00-2.08. The centromeric index is 32.41-50.00, and relative lengths are $8.52-17.53 \%$ (Table 2). Somatic metaphase chromosomes and idiograms are given in Figs. 1a and 2a.

C. virgata Lam.: This taxon perennial with the woody base and several stems. It's growing on dry hills, steppe, dry waste ground, between 100 and $2000 \mathrm{~m}$ (Davis 1975). The somatic chromosome number of this species was found to be $2 n=36$. The chromosome length ranges 1.63 to $6.00 \mu \mathrm{m}$, and the total length of the haploid complement was $63.47 \mu \mathrm{m}$. It consists of $3 \mathrm{M}, 8 \mathrm{~m}$, and $7 \mathrm{sm}$ chromosomes. Chromosome arm ratios are 1.00-3.60. Centromeric index is $22.37-50.00$, and relative lengths are $2.56-9.45 \%$. Two of the sm chromosomes have satellites (Table 2). Somatic metaphase chromosomes and idiograms are given in Figs. $1 \mathrm{~b}$ and $2 \mathrm{~b}$.

C. balsamita Lam.: This taxon is annual, Iran-Turan Element. It's growing on the steppe and fallow fields, between altitudes of 650 and $1900 \mathrm{~m}$ (Davis 1975). The somatic chromosome number of this species was found to be $2 n=26$. The chromosome length ranges from 1.60 to $4.22 \mu \mathrm{m}$, and the total length of the haploid complement was $33.94 \mu \mathrm{m}$. It consists of $1 \mathrm{M}, 7 \mathrm{~m}$, and $5 \mathrm{sm}$ chromosomes. Chromosome arm ratios are 1.00-2.36. Centromeric index is 29.68-50.00, and relative lengths are $4.71-12.43 \%$ (Table 2). Somatic metaphase chromo- 

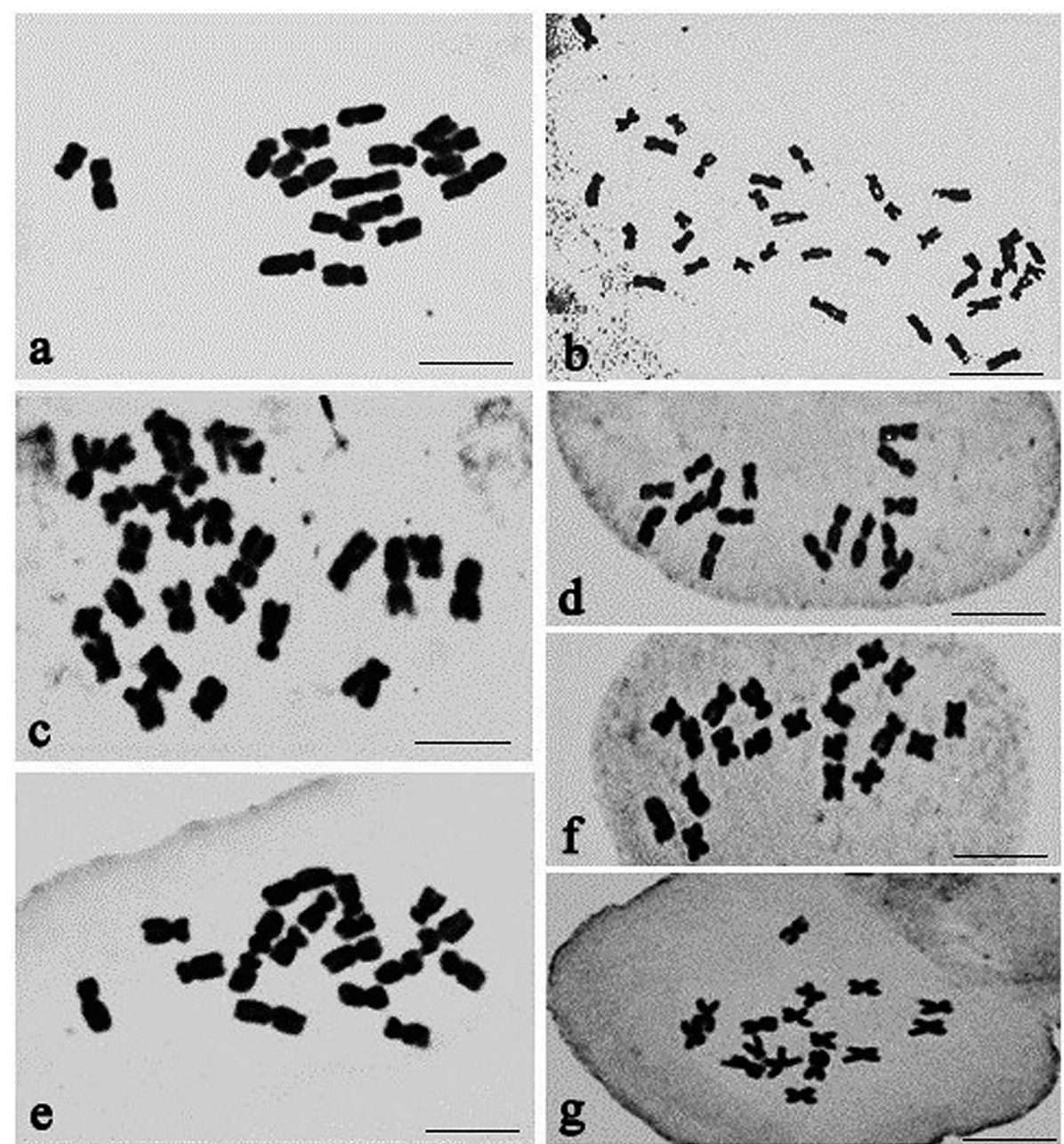

Fig. 1. Somatic metaphase chromosomes in Centaurea taxa. a. C. aggregata ssp. aggregata $(2 n=18)$, b. C. virgata $(2 n=36)$, c. C. balsamita $(2 n=26)$, d. C. behen $(2 n=16)$, e. C. cynarocephala $(2 n=18)$, f. C. iberica $(2 n=20)$, g. C. solstitialis ssp. solstitialis $(2 n=16)$. Scale bars $=10 \mu \mathrm{m}$.
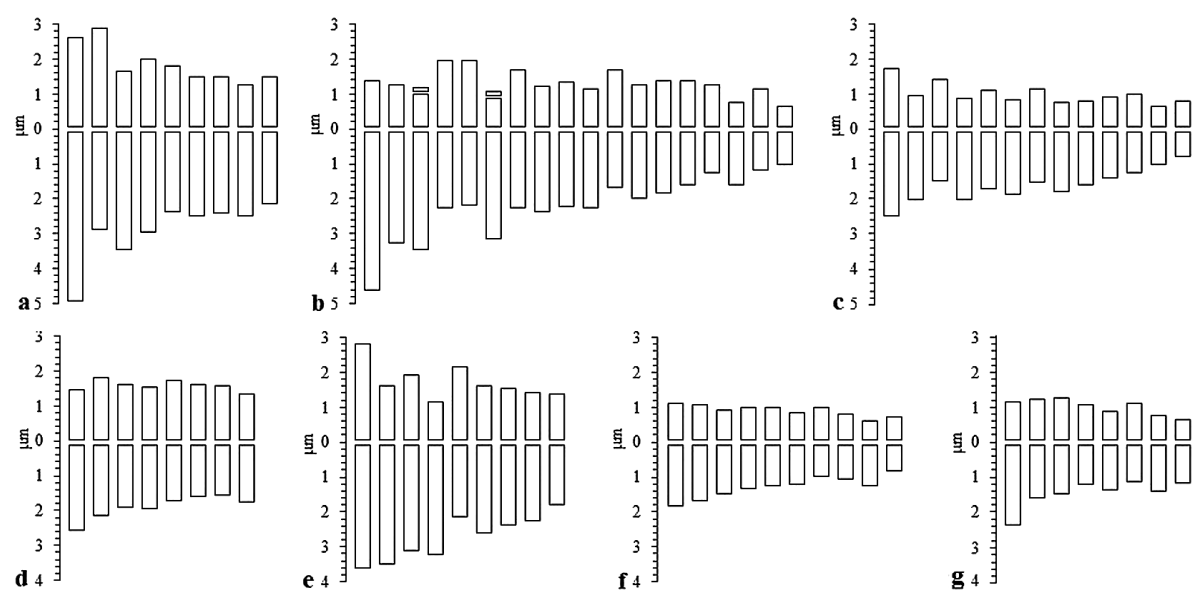

Fig. 2. Haploid idiograms in Centaurea taxa. a. C. aggregata ssp. aggregata, b. C. virgata, c. C. balsamita, d. C. behen, e. C. cynarocephala, f. C. iberica, g. C. solstitialis ssp. solstitialis.

somes and idiograms are given in Figs. 1c and 2c.

C. behen L.: This taxon is perennial, Iran-Turan Element. It's growing on rocky slopes, fallow fields, between 340 and $1730 \mathrm{~m}$ (Davis 1975). The somatic chromosome number of this species was found to be $2 n=16$. The chromosome length ranges from 3.07 to $4.03 \mu \mathrm{m}$ and the total length of the haploid complement was $27.81 \mu \mathrm{m}$. It consists of $3 \mathrm{M}, 4 \mathrm{~m}$, and $1 \mathrm{sm}$ chromosomes. Chromosome arm ratios are 1.00-1.76. Centromeric index is $36.22-50.00$, and relative lengths are $11.03-$ $14.49 \%$ (Table 2). Somatic metaphase chromosomes and idiograms are given in Figs. 1d and 2d. 
C. cynarocephala Wagenitz: This taxon is biennial, Iran-Turan Element. Its distributed on limestone cliffs, dry hills, between 1150 and $1200 \mathrm{~m}$ (Davis 1975). The somatic chromosome number of this species was found to be $2 n=18$. The chromosome length ranges from 3.18 to $6.41 \mu \mathrm{m}$ and the total length of the haploid complement was $40.15 \mu \mathrm{m}$. It consists of $1 \mathrm{M}, 6 \mathrm{~m}$, and $2 \mathrm{sm}$ chromosomes. Chromosome arm ratios are 1.00-2.79. The centromeric index is 26.37-50.00, and relative lengths are $7.89-15.96 \%$ (Table 2). Somatic metaphase chromosomes and idiograms are given in Figs. 1e and 2e.

C. iberica Trev. ex Sprengel: This taxon growing on fields, roadsides and waste land, c. $2300 \mathrm{~m}$ (Davis 1975). The somatic chromosome number of this species was found to be $2 n=20$. The chromosome length ranges from 1.57 to $2.95 \mu \mathrm{m}$ and the total length of the haploid complement was $21.93 \mu \mathrm{m}$. It consists of $1 \mathrm{M}, 8 \mathrm{~m}$, and $1 \mathrm{sm}$ chromosomes. Chromosome arm ratios are 1.00 2.03. The centromeric index is 32.97-50.00, and relative lengths are $7.15-13.45 \%$ (Table 2). Somatic metaphase chromosomes and idiograms are given in Figs. 1f and $2 \mathrm{f}$.

C. solstitialis L. ssp. solstitialis: This taxon distributed on Pinus forests, dry slopes, fallow fields and waste places, c. $1900 \mathrm{~m}$ (Davis 1975). The somatic chromosome number of this species was found to be $2 n=16$. The chromosome length ranges from 1.81 to $3.53 \mu \mathrm{m}$ and the total length of the haploid complement was $19.80 \mu \mathrm{m}$. It consists of $1 \mathrm{M}, 4 \mathrm{~m}$, and $3 \mathrm{sm}$ chromosomes. Chromosome arm ratios are 1.00-2.09. The centromeric index is $32.29-50.00$, and relative lengths are 9.14-17.82\% (Table 2). Somatic metaphase chromosomes and idiograms are given in Figs. $1 \mathrm{~g}$ and $2 \mathrm{~g}$.

\section{Discussion}

The genus Centaurea has been a problematic taxon in the world, also in Turkey. High endemism ratio shows that Turkey is one of the gene centers of the genus. Therefore, in this study, we focused on this genus. Karyotype analysis of the examined Centaurea taxa showed that the taxa have $x=8,9,10$ and 13 basic chromosome number and all of them are diploid except for C. virgata. Analysis of the karyotype formulae indicated that chromosomes of seven studied Centaurea taxa generally have $\mathrm{m}$ and sm karyotypes. An M karyotype is also observed. The mean chromosome length is 1.57$6.00 \mu \mathrm{m}$. The smallest chromosome length is in diploid specimens of $C$. iberica while the longest chromosome length was seen in tetraploid specimens of $C$. virgata. The centromeric index ranges from 22.37 to 50.00 , and relative lengths from 2.56 to $17.82 \%$. The intrachromosomal asymmetry index (A1) ranges from 0.14 to $0.35 \mu \mathrm{m}$. Interchromosomal asymmetry index (A2) varies between 0.10 and 0.28 .

Chromosome number of C. aggregata ssp. aggregata was first reported by Bakhshi Khaniki, and its $2 n=18$
(Bakhshi Khaniki 1996). Our investigations confirm these dates, the determined chromosome number being of $2 n=18$. A tetraploid chromosome numbers were observed $2 n=4 x=36$ in the specimens of $C$. virgata. Two of the submedian chromosomes have satellites (satchromosome) was observed in $C$. virgata (Figs. $1 \mathrm{~b}$ and 2b). Ghaffari was reported that chromosome number of C. virgata $2 n=18$ (Ghaffari and Chariat-Panahi 1985, Ghaffari 1989). By Bakhshi Khaniki and Shahraki were reported chromosome number of $C$. balsamita $2 n=26$ (Bakhshi Khaniki 1996, Ghaffari and Shahraki 2001). Our investigations confirm these dates, the determined chromosome number being of $2 n=26$. Somatic chromosome number is $2 n=26,32,34$ of $C$. behen were reported in the literatüre (Chouksanova et al. 1968, Ghaffari and Shahraki 2001, Romaschenko et al. 2004). Our investigations confirm these dates, the determined chromosome number being of $2 n=16$. The somatic chromosome numbers were determined as $2 n=20$ in the specimens of $C$. iberica. $2 n=20$ chromosomes of this species were reported in the literatüre (Kuzmanov et al. 1986, Ghaffari 1989, Hellwig 1994, Garcia-Jacas et al. 1997). The somatic chromosome numbers was determined as $2 n=2 x=16$ of $C$. solstitialis ssp. solstitialis. $2 n=2 x=16$ chromosomes of this species were reported in the literature (Van Loon 1980, Georgiadis and Christodoulakis 1984, Ozturk et al. 2009).

In this study, chromosome numbers of seven Turkish Centaurea taxa were established. Numerous counts were reported for $C$. agregata ssp. agregata, $C$. virgata, $C$. balsamita, C. behen, C. iberica and C. solstitialis in previous studies. But, as far as we know, the chromosome number and morphology of the taxa $C$. cynarocephala are newly reported here. This study will contribute to further studies on the karyotype properties and implications on systematic of genus Centaurea from Turkey.

\section{Acknowledgements}

The authors want to thank Firat University Scientific Projects Research Fund (FUBAP) [project no. FF.12.02.] for financial support.

\section{References}

Altintas, A., Kose, Y. B., Yucel, E., Demirci, B. and Baser, K. H. C. 2004. Composition of the essential oil of Centaurea dichroa. Chem. Nat. Compd. 40: 604-605.

Bakhshi Khaniki, G. 1996. Karyological studies in six taxa of the genus Centaurea (Compositae) from Iran. Bot. Chr. (Patras) 12: 55-65.

Bancheva, S. and Greilhuber, J. 2006. Genome size in Bulgaria Centaureas 1. (Asteraceae). Plant Syst. Evol. 257: 95-117.

Baytop, T. 1999. Treatment with Plants in Turkey. Nobel Tip Kitapevi, Istanbul.

Chouksanova, N. A., Sveshnikova, L. I. and Alexandrova, T. V. 1968. A new evidence on chromosome numbers in species of the family Compositae Giseke. Cytologia 10: 381-386. 
Davis, P. H. 1975. Centaurea L. In: Davis, P. H. (ed.). Flora of Turkey and the East Aegean Islands Vol. 5. Edinburgh University Press, Edinburgh.

Davis, P. H., Mill, R. R. and Tan, K. 1988. Centaurea L. In: Davis, P. H., Mill, R. R. and Tan, K. (eds.). Flora of Turkey and the East Aegean Islands Vol. 10 (Suppl.). Edinburgh University Press, Edinburgh.

Dittrich, M. 1977. Cynareae, Systematic Review. In: Heywood, V. H., Harborne, J. B. and Turner, B. L. (eds.). The Biology and Chemistry of Compositae. Academic Press, New York. pp. 999-1015.

Garcia-Jacas, N., Susanna, A., Ilarslan, R. and Ilarslan, H. 1997. New chromosome counts in the subtribe Centaureinae (Asteraceae, Cardueae) from West Asia. Bot. J. Linn. Soc. 125: 343-349.

Garcia-Jacas, N., Uysal, T., Romashchenko, K., Suarez-Santiago, V. N., Ertugrul, K. and Susanna, A. 2006. Centaurea revisited: a molecular survey of the Jacea group. Ann. Bot. 98: 741-753.

Georgiadis, T. and Christodoulakis, D. 1984. Contribution a l'etude cytogeographique des Centaurees de I'le de Samos. Candollea 39: 307-318.

Ghaffari, S. M. 1989. Chromosome studies in Iranian Compositae. Iran. J. Bot. 4: 189-196.

Ghaffari, S. M. and Chariat-Panahi, S. 1985. In: Löve, A. (ed.). Chromosome number reports LXXXVIII. Taxon 34: 549.

Ghaffari, S. M. and Shahraki, M. A. 2001. Some chromosome counts and meiotic behavior in Centaurea species from Iran. Iran. J. Bot. 9: 11-18.

Gomurgen, A. N. 2006. Chromosome numbers of some species belonging to the genus Centaurea. In: Bosgelmez, A. (ed.). Gölbaş1 Mogan Lake Andesite Stone Centaurea tchihatcheffii. Bizim Büro Basımevi, Ankara. pp. 404-455.

Greuter, W. 2003. The EuroMed treatment of Cardueae (Compositae) generic concepts and required new names. Willdenowia 33: 49-61.

Guner, A. 2000. Centaurea L. In: Guner, A., Ozhatay, N., Ekim, T. and Baser, K. H. C. (eds.). Flora of Turkey and the East Aegean Islands Vol. 11. (Suppl.). Edinburgh University Press, Edinburgh. pp. $163-164$.

Gurbuz, I. and Yesilada, E. 2007. Evaluation of the antiulcerogenic effect of the sesquiterpene lactones from Centaurea solstitialis ssp. solstitialis by using various in vivo and biochemical techniques. J. Ethnopharmacol. 112: 284-295.

Hellwig, F. H. 1994. Choromosomenzahlen aus der Tribus Cardueae (Compositae). Willdenowia 24: 219-248.

Hellwig, F. H. 2004. Centaureinae (Asteraceae) in the Mediterranean history of ecogeographical radiation. Plant Syst. Evol. 246:
$137-162$.

Kazmi, S. M. A. 1964. Revision der Gattung Carduus (Compositae) II. Mitt. Bot. Staatssamml. Münch. 5: 279-550.

Kiran, Y., Turkoglu, I., Kırılmaz, F., Arabacı, T., Sahin, A. and Bagci, E. 2012. Karyological investigation of six Achillea L. (Asteraceae) species growing in Turkey. Caryologia 65: 101-105.

Kuzmanov, B. A., Georgieva, S. B. and Nikolova, V. A. 1986. Chromosome numbers of Bulgarian flowering plants. I. Fam. Asteraceae. Fitologija 31: 71-74.

Levan, A., Fredga, K. and Sandberg, A. A. 1964. Nomenclature for centromeric position of chromosomes. Hereditas 52: 201-220.

Ozturk, M., Martin, E., Dinc, M., Duran, A., Ozdemir, A. and Cetin, O. 2009. A cytogenetical study on some plants taxa in Nizip region (Aksaray, Turkey). Turk. J. Biol. 33: 35-44.

Romaschenko, K., Ertugrul, K., Susanna, A., Garcia-Jacas, N., Uysal, T. and Arslan, E. 2004. New chromosome counts in the Centaurea jacea group (Asteraceae, Cardueae) and some related taxa. Bot. J. Linn. Soc. 145: 345-352.

Romero Zarco, C. 1986. A new method for estimating karyotype asymmetry. Taxon 35: 526-530.

Stebbins, G. L. 1971. Chromosomal Evolution in Higher Plants. Edward Arnold. London.

Tamamschian, S. G. 1963. Carduus L. In: Bobrov, E. G. and Cherepanov, S. K. (eds.). Flora of the USSR. Vol. 28. Moscow/Leningrad. pp. 4-39.

Van Loon, J. C. 1980. In: Löve, A. (ed.). Chromosome number reports LXIX. Taxon 29: 718-720.

Wagenitz, G. 1975. Centaurea L. In: Davis, P. H. (ed.). Flora of Turkey and the East Aegean Islands. Vol. 5. Edinburgh University Press, Edinburgh. pp. 465-585.

Wagenitz, G. 1986. Centaurea in south-west Asia: Patterns of distribution and diversity. Proc. R. Soc. Edinb. 89b: 11-21.

Wagenitz, G. and Hellwig, F. H. 1996. Evolution of Characters and Phylogeny of the Centaureinae. In: Hind, D. J. N. and Beentje, H. G. (eds.). Compositae: Systematics. Proceedings of the International Compositae Conference Kew 1994. Royal Botanic Gardens, Kew. pp. 491-510.

Wagenitz, G. and Hellwig, F. H. 1997. Eine neue und eine verschollene Centaurea-Art aus der Türkei und eine neue Volutaria-Art (Compositae-Cardueae). Ann. Naturhist. Mus. Wien B 99: 175-181.

Yesilada, E., Gurbuz, I., Bedir, E., Tatli, I. and Khan, I. A. 2004. Isolation of antiulcerogenic sesquiterpene lactones from Centaurea solstitialis ssp. solstitialis through bioassay-guided fractionation procedures in rats. J. Ethnopharmacol. 95: 213-219. 